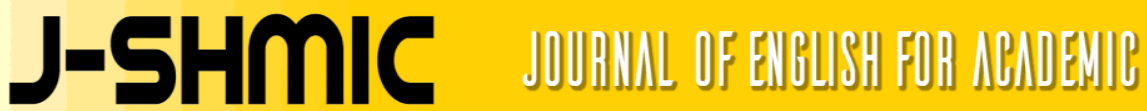

\section{Applying Impromptu Speech Technique to Improve Students' Speaking Ability at the Fourth Semester Students of STIBA Persada}

\author{
Rauf TetukoBarruansyah \\ Sekolah Tinggi Ilmu Bahasa Asing (STIBA) PersadaBunda \\ email: rauftetuko@gmail.com
}

\begin{abstract}
Based on the writer's preliminary study, it was found that the speaking ability of the students were still low. Some of students were not able to pronounce well, were not able to express their ideas, and were afraid of making mistakes when they were speaking. All of those problems were caused by several factors, one of them was the way of teaching was not appropriate for the students. In this research, the writer applied Impromptu Speech technique which has been proven can improve students' speaking ability, it is one teaching technique that is very useful for teaching speaking. This technique enables students to develop their capability to think on their feet, organize ideas quickly, and speak informatively and confidently about variety of topics. The subject of this research was the fourth semester students of Sekolah Tinggi Ilmu Bahasa Asing (STIBA) PersadaBunda, and the object was the effect of applying Impromptu Speech technique. The writer used simple sampling to take the sample. The writer used Non Equivalent control group design that used one group as the experimental class and one group as control class. The writer used Independent Sample t-test to analyze the data. Based on the data analysis, Consideration Sig (2tailed) $t_{0}=0.000$ is lower than Sig ( 2 tailed) $t_{\text {table }}=0.005$, it means Ha was accepted and $\mathrm{H}_{0}$ is rejected. So, it can be concluded that there is a significant effect of applying Impromptu Speech technique to improve students' speaking ability at the fourth semester students of STIBA PersadaBundaPekanbaru
\end{abstract}

Keywords: Impromptu Speech Technique, Speaking Ability

\section{Penggunaan Teknik Mengajar Impromptu Speech untuk Meningkatkan Kemampuan Berbicara pada Mahasiswa Semester 4 di STIBA Persada Bunda}

\begin{abstract}
Abstrak
Berdasarkan pada pemantauan awal penulis, ditemukan bahwa kemampuan berbicara bahasa Inggris mahasiswa masih rendah. Beberapa mahasiswa tidak mampu melafalkan bahasa Inggris dengan tepat, tidak mampu mengekspresikan ide-ide mereka, dan takut untuk membuat kesalahan ketika mereka berbicara bahasa Inggris. Semua permasalahan tersebut terjadi karena banyak faktor, salah satunya adalah tidak cocoknya penggunaan strategi yang tepat dalam mengajar speaking. Didalam penelitian ini, peneliti menggunakan tekhnik mengajar Impromptu speech yang telah terbukti mampu meningkatkan kemampuan berbicara bahasa Inggris, ini adalah salah satu tekhnik yang sangat berguna untuk mengajar speaking. Tekhnik ini membuat
\end{abstract}


siswa mampu mengembangkan kemampuan mereka untuk berpikir pada kemamouan mereka, mengorganisasi ide ide dengan cepat, dan berbicara tentang macam macam topic dengan secara informative dan percaya diri. Subyek penelitian ini adalah mahasiswa semester 4 Sekolah Tinggi Ilmu Bahasa Inggris (STIBA) Persada Bunda, dan obyeknya adalah efek penggunaan "Impromptu Speech". Peneliti menggunakan Simple Sampling dalam mengambil Sampel. Penulis penggunakan Desain Non Equivalent control group design yang menggunakan satu kelas sebagai kelas eksperimen dan satu kelas sebagai kelas kontrol. Peneliti menggunakan Independent Sample t-test untuk menganalisa data. Berdasarkan data analisis, signifikansi pertimbangan ( 2 tailed) $t_{0}=$ lebih rendah daripada signifikansi $(2$ tailed $) t_{\text {table }}=0.005$, itu bearti bahwa $\mathrm{H}_{\mathrm{a}}$ diterima dan $\mathrm{H}_{0}$ ditolak. Jadi, bisa disimpulkan bahwa ada efek yang signifikan penggunaan Tekhnik Impromptu Speech untuk meningkatkan kemampuan berbicara bahasa Inggris mahasiswa semester 4 di STIBA Persada Bunda Pekanbaru.

\section{KataKunci: Teknik Impromptu, KemampuanBerbicara}

\section{INTRODUCTION}

Speaking is a productive language skill. It consists of producing systematic verbal utterance to convey meaning. Spoken language and written language are differing in much significant ways. In speaking, we have to share an idea directly, without thinking for its writing. It means that it is totally natural and there is limited time for planning and editing speech during conversation even managing the components of language that must work together when we speak is very demanding indeed. It is unlike writing. We have the chance to plan what we are going to share in unlimited time and doing either editing or revision. Speaking is one of core for success in education.

Nunan states (2003:48) Speaking is harder than reading, writing, or listening for two reasons. First, unlike reading or writing, speaking happens in real time: usually

J-SHMIC, Vol 5, No 2, August 2018 the person you are talking to is waiting for you to speak right then. Second, when you are speaking, you cannot edit and revise what you to say, as you can when you are writing. Thompson states (1977:64) that one's ability in language can be sized by his or her speaking proficiency. It needs more practice. Language without practice is nothing. Mastering speaking should be supported by many aspects. They are: mastery of grammar, vocabulary, reading motivation, and mastering in expressing ideas. They are interrelated each others.

According to Hasibuan (2007: 101) Language learners need to recognize that speaking involves three areas of knowledge:

1. Mechanics (pronunciation, grammar, and vocabulary): using the right words in the right order with the correct pronunciation. 
2. Function (transactional and interactional): knowing when clarity of message is essential (transaction/information exchange) and when precise understanding is not required (interaction/ relationship building)

3. Social and culture rules and norms (turn-talking, rate of speech, length of pauses between speakers, relative roles of participants):

understanding how to take into account who is speaking to whom, in what circumstances, about what, and for what reason.

By using impromptu speech technique, the researcher expects to improve students' speaking ability. In elaborating a theoretical rationale for the natural approach, the lecturerdid lecture's teaching enjoyably.Lecture lets the students express their ideas free as much as they can, and sometimes they mix either bahasa Indonesia or the target language. The students may speak without judge them on grammatical order by the lecturer. In addition, English is taught by professional lecturers of English. They have tried to teach their students maximally inorder to make their students interested in and habituated to expressing their ideas by using the target language.

In outside of classroom the lecturers also support it by providing other programs such as debate, English club, and English day. Those are proposed to improve students' speaking ability. Ideally, the students are able to speak English well as well as speaking activities applied to the students are to assist them to speak English well. But, what is expected from the teaching and the activities is contrary to the reality.

Referring to the description above, actually the students have been taught speaking maximally. In fact, some of the students in STIBA PersadaBundacannot speak English very well. It can be seen from the following phenomena:

a. Someof the students are not able to pronounce English words well.

b. Someof the students are not able to express their ideas in English.

c. Someof the students have difficulties in differentiating part of speech.

d. Some of the students are afraid of making mistakes to speak English.

e. Someof the students are not able to choose vocabulary accurately in expressing oral language.

f. Someof the students have lack of self confidence when they were speaking with each others.

To improve the students' ability in speaking, it is necessary for language lecturer to foster speaking skill on their students, it needs an appropriate technique to be used as a solution in teaching and learning process. There is actually a technique that can help lecturer to improve the students' speaking ability, called 
impromptu speech-speaking without preparation. According to JefMenguin (2010), there are some benefits of an impromptu speech technique: it can improve oral expression of thought, develop confidence in public speaking, think quickly on your feet, and develop leadership and communication skills. Those are supported by Dale on page 29 of his thesis. In addition, referencing to Dr. Cecilia B-Ikeguchi (1996:1),this technique is very challenging activity for his English students who would, at the end of the year, say: "this class really taught me how to speak in English." Alsoan impromptu speech can reveal the student's ability to organize thoughts quickly, confidently, naturally and logically. However, it can make them creative and imaginative interpretation of the designated topic, supported by varied materials. The material given is something that related to a variety of everyday words, phrases and topics.Besides, there are some disadvantages of this technique: for those who do not have much knowledge and insight, they will make the speaker's pivotal speech turmoil

Impromptu speech technique is one teaching technique that is very useful for teaching speaking. This technique enables students to develop their capability to think on their feet, organize ideas quickly, and speak informatively and confidently about variety of topics. In addition, "Impromptu speech" also called thinking on your feet. It refers to being able to organize one's ideas quickly and speak about a subject without an advance time to prepare. People actually use it all of the time in most of conversations with friends, parents, lectures, and others that are really short impromptu talks. Besides, answering question, giving opinion, or sharing knowledge about many things on daily bases also can be called an impromptu speech.

According to Preston (1992:3) as cited by David E. Williams that impromptu speaking provides more than an exciting form of competition for students. In addition, impromptu speaking is a speech and debate consolation event that involves eight minute speech, with up to three of these eight minutes available for use as preparation time (known as prep time, or simply prep). In other words, Impromptu speaking is the same as impromptu speech. Actually, this technique can be utilized improving either student's ability in speaking or listening but in this research the researcher focuses to use this technique for improving speaking ability only.

According to Wah $(2006: 88)$ to gauge the success of our speech, impromptu speech is important to be constantly on guard for feedback while we are delivering. This technique will have to choose if we are suddenly asked to "say a few words". There are two kinds of situation in which we are take a part in speaking, they are : the first is planned speech, where the speakers have prepare and possibly rehearsed their presentation in advance, or they express well thoughout points and opinion, which they may have voiced many times before. The second is unplanned speech, in 
contras, is spoken in the spur of the moment, often in reaction to other speakers. Impromptu speech technique is one forms of unplanned speech.

According to Williamson (2008:17), impromptu speaking is the most direct way to provide both fluency and confident effectively in deriving the ideas. As the spontaneous speech, it is very different from the structure of phrases and clauses in written language. There are many types of phrase and clause construction that occur frequently in writing but very rarely in speech and other types that occur frequently in speech; representation of conversation but never in writing. These might be seen to the person who has high education. However, before students speak, the lecture invites them to think even the topic is unknown variable. For example if there is a student asked to follow speech competition or debate contest by giving unknown topics because impromptu speaking require that the students develop a theses, illustrate with specific examples from their reading, personal experience and current event that they organize their information to allow for a meaningful conclusion, So, this technique can helps the learners think and recall a list of insight and experience in their mind-topics that they were studying in school, books and so fort what they were reading.

Furthermore, impromptu speech technique can serve several purposes in an oral skill class. It makes the students more actual practice with speaking the language, but it also forces them to think, and speak in gaining ideas without any notes or memorization. They should keep talking even thought using hesitations; um, well, eh, sort of, and etc., because those are an acceptable speaking strategy.

For all the theory and explanation above, it clear that impromptu speech technique enable students to organize one's ideas quickly and prepares students to communicate intelligently on the spur of the moment beyond the classroom into society. In this research, it is meant a very challenging technique used by the researcher to improve students' speaking ability of the fourth semester students of STIBA PersadaBundaPekanbaru. This technique is actually used by all of people naturally in their daily real talking. Because sometimes, we do not need much time to think before speaking. It is natural spontaneously in the spur of moment-unplanned speech. So this way, this technique needs to be considered being applied in teaching learning activity in improving students' speaking ability and behaving students to take apart in using English language all of the time. Besides, this technique is expected can recall the students insight and experience that they were studied and read from any resources.

\section{REVIEW OF LITERATURE}

In 2007, Minghau Hou conducted the research entitled" A New Approach to Public Speaking Course in ESL classroom". The researcher took this research as a related finding because there are close relationships 
among impromptu speaking, debating, and public speaking. Debating is one way of doing impromptu speech technique and public speaking is one of the situations for using the impromptu speaking. Hou has published his research finding in a journal. The research was conducted at school of foreign studies Yangtze University China. He found that by the practicing through of English speaking and debating courses help the students develop logical reasoning and English speaking competences.

Based on the survey result, about $85 \%$ of the students think this technique improved their ability to utilize English integrally, $89 \%$ of the students are more strongly motivated to learn English and $77 \%$ more strongly motivated to speak English. Hou suggests that the technique can be considered to be as the fundamental courses for systematically training higrade English major' spoken communication ability.

There are several purposes of impromptu speech technique as follows:

1. To offer students a unique forensics activity and valuable training in critical thinking, analysis, organization and delivery for situations outside of competition.

2. To offer students enjoyable forensics activity and valuable training in critical thinking, analysis, organization and delivery for situations outside of competition.

3. To offer the students do not need much preparation in delivering speech.

J-SHMIC, Vol 5, No 2, August 2018
4. To offer students become tentatively reasoned response. Reasoned response will offer a means to incorporate these educational goals in an event that should still be considered fun, thrilling and challenging to students.

5. To helps the students more of a socially significant activity.

6. To offer the students become competent in delivering a speech.

7. To prepare students to communicate intelligently on the spur of the moment beyond the classroom into society.

The advantages of impromptu speech technique

There are some the advantages of using this technique. Actually, besides improving speaking students' ability in speaking, it can also improve their listening. They are:

1. Improving oral expression of thought develops confidence in public speaking, think quickly on your feet, and develop leadership and communication skill.

2. The impromptu speech allow students to work on both fluency and presentation skill.

3. This technique enables to know the students' proficiency of speaking naturally in real time even their knowledge and insight. The materials for impromptu speaking are chosen by the lecture according to the students' interest level, rather than picking out topics from text materials. This activity combines training students for public speaking and testing comprehension of materials given. 
4. The students are simultaneously engaged in different activities instead of getting bored listening to all the classmates' speeches.

5. The class is given a chance to watch a variety of materials - although short - in a limited class time.

6. It is necessary to modify the speech while speaking depends on audiences' mood.

7. Trialing to make the process of the speech becomes coherence and consistent.

\section{The Standard procedure of Impromptu Speech Technique}

The standard procedures of impromptu speech techniques are:

1. The lectureexplains the material

2. The lecture prepares some topics or questions from the material discussed that depends on the large of the class.

3. The lecture divides students into some groups that consist of four or five students.

4. The lecture assigns each group a topic or question to each group randomly by lottery.

5. The lecture asks each student in a group to perform his/her topic continued by the next groups and the other groups may give a question to the group performance.

\section{a. Accent}

\begin{tabular}{|l|l|}
\multicolumn{4}{|c|}{ Table 1 } \\
\hline Score & \multicolumn{1}{|c|}{ Requirement } \\
\hline 1. & Pronunciation frequently unintelligible. \\
\hline 2. & $\begin{array}{l}\text { Frequent gross error and a very heavy accent make } \\
\text { understanding difficult, require frequently repetition. }\end{array}$ \\
\hline 3 & $\begin{array}{l}\text { "Foreign accent" requires concentrated listening, and } \\
\text { mispronunciations lead to occasional misunderstanding and } \\
\text { apparent errors in grammar of vocabulary. }\end{array}$ \\
\hline
\end{tabular}




\begin{tabular}{|l|l|}
\hline 4 & $\begin{array}{l}\text { Marked "Foreign accent" and occasional mispronunciations } \\
\text { which do not interfere with understanding. }\end{array}$ \\
\hline 5 & $\begin{array}{l}\text { No conspicuous, mispronunciations, but would not be taken } \\
\text { for a native speaker. }\end{array}$ \\
\hline 6 & Native pronunciation, with no trace of "foreign accent" \\
\hline
\end{tabular}

\section{b. Grammar}

\section{Table 2}

c. G
\begin{tabular}{|l|l|}
\hline Scare & \multicolumn{1}{c|}{ Grammar } \\
\hline 1 & Grammar almost entirely inaccurate except in stock phrase. \\
\hline 2 & $\begin{array}{l}\text { Constant errors showing control of view major patterns and } \\
\text { frequently preventing communication. }\end{array}$ \\
\hline 3 & $\begin{array}{l}\text { Frequent errors showing some major patterns uncontrolled and } \\
\text { causing occasional irritation and misunderstanding. }\end{array}$ \\
\hline 4 & $\begin{array}{l}\text { Occasional errors showing imperfect control of some pattern but } \\
\text { no weakness that causes misunderstanding. }\end{array}$ \\
\hline 5 & Few errors, with no patterns of failure. \\
\hline 6 & No more than two errors during the interview. \\
\hline
\end{tabular}

\section{c.vocabulary}

\section{Table 3}

\begin{tabular}{|l|l|}
\hline Score & Requirement \\
\hline 1 & Vocabulary inadequate for even the simple conversation. \\
\hline 2 & $\begin{array}{l}\text { Vocabulary limited to basic personal and survival areas (time, } \\
\text { food, transportation, family, etc.). }\end{array}$ \\
\hline 3 & $\begin{array}{l}\text { Choice of words sometimes inaccurate, limitations of vocabulary } \\
\text { prevent discussion of some common professional and social } \\
\text { topics. }\end{array}$ \\
\hline 4 & $\begin{array}{l}\text { Professional vocabulary adequate to discuss special interest; } \\
\text { general vocabulary permits discussion of any non-technical } \\
\text { subject with some circumlocutions. }\end{array}$ \\
\hline 5 & $\begin{array}{l}\text { Professional vocabulary broad and precise; general vocabulary } \\
\text { adequate to cope with complex practical problems and varied } \\
\text { social situations. }\end{array}$ \\
\hline 6 & $\begin{array}{l}\text { Vocabulary apparently as accurate and extensive as that of an } \\
\text { educated native speaker. }\end{array}$ \\
\hline
\end{tabular}




\section{d. Fluency}

Table 4

\begin{tabular}{|l|l|}
\hline Score & Requirement \\
\hline 1 & $\begin{array}{l}\text { Speech is so halting and fragmentary that conversation is virtually } \\
\text { impossible. }\end{array}$ \\
\hline 2 & $\begin{array}{l}\text { Speech is very slow and uneven except for short or routine } \\
\text { sentences. }\end{array}$ \\
\hline 3 & $\begin{array}{l}\text { Speech is frequently hesitant and jerky; sentences may be left } \\
\text { uncompleted. }\end{array}$ \\
\hline 4 & $\begin{array}{l}\text { Speech is occasionally hesitant, with some unevenness caused by } \\
\text { rephrasing and grouping for words. }\end{array}$ \\
\hline 5 & $\begin{array}{l}\text { Speech is effortless and smooth, but perceptively non-native an } \\
\text { speed and evenness. }\end{array}$ \\
\hline 6 & $\begin{array}{l}\text { Speech on all professional and general topics as effortless and } \\
\text { smooth as a native speaker's. }\end{array}$ \\
\hline
\end{tabular}

e. Comprehension

Table 5

\begin{tabular}{|l|l|}
\hline Score & Requirement \\
\hline 1 & Understands too title for the simplest types of conversation. \\
\hline 2 & $\begin{array}{l}\text { Understands only show, very simple speech on common social and } \\
\text { touristic topics; requires constant repetition and rephrasing. }\end{array}$ \\
\hline 3 & $\begin{array}{l}\text { Understands careful, somewhat simplified speech when engaged in } \\
\text { a dialogue, but may require considerable repetition and rephrasing. }\end{array}$ \\
\hline 5 & $\begin{array}{l}\text { Understands quite well normal educated speech when engaged in a } \\
\text { dialogue, but requires occasional repetition or rephrasing. }\end{array}$ \\
\hline 6 & $\begin{array}{l}\text { Understands everything in normal educated conversation except for } \\
\text { slurred speech. }\end{array}$ \\
\hline Understand everything in both formal and colloquial speech to be \\
expected of an educated native speaker.
\end{tabular}

Note: for non-native speaker, 5 is the highest score.

The speaking result was evaluated by concerning five components, and each component had score or level. Each component had 20 as the highest score, and the total of all components is 100. The specification of the test is as follow: 
Table 6

The Specification of the Test

\begin{tabular}{|c|c|c|}
\hline No & Speaking skill & The highest score \\
\hline 1 & Accent & 20 \\
\hline 2 & Grammatical & 20 \\
\hline 3 & Vocabulary & 20 \\
\hline 4 & Fluency & 20 \\
\hline 5 & Comprehension & 20 \\
\hline & Total & 100 \\
\hline
\end{tabular}

\section{METHOD}

The type of this research is Experimental research that is testing an idea (or practice or procedure) to determine whether it influences an outcome or dependent variable. In addition, an experiment is the quantitative approach that provides the greatest degree of control over the research procedures. In this research, the researcher used quasi-experimental design with nonequivalent control group. It was an appropriate one to this research in order to know the significant effect of using impromptu speech technique toward students' speaking ability at STIBA PersadaBundaPekanbaru. In conducting this research, the researcher took two groups; one class was as an experimental class taught by impromptu speech technique and another one was as a control class taught by natural approach. In the experimental class, the students were administered by giving pre-test at the beginning of the teaching learning in order to know students' speaking ability. Then, there was a treatment at the middle. There was a posttest at the end of the teaching learning processes in order to know the effect of using impromptu speech technique toward students' speaking ability. So, the design of this research can be illustrated as follows:

TABLE 7

The Research Design

\begin{tabular}{|l|l|l|l|l|l|}
\hline 1 & Experimental Class & Sample & Pre-test & Treatments & Post-test \\
\hline 2 & Control Class & Sample & Pre-test & No treatment & Post-test \\
\hline
\end{tabular}




\section{The Technique of Collecting Data}

The test used of this research was oral presentation test. The students were given a task to speak in the spur of the moment. According to Weir (1990:75), there are some advantages of this test technique. They are: first, it is often very effective to get the candidate to talk about himself first then eliciting a sufficient sample of candidate's speech for sensible assessments to be made. Second, the candidates might have to perform in the target situation. The test was done in twice; pretest-posttest. Here, the lecture gave the task for students to speak in the spur of the moment by given topic. The task given in pre-test was also given to the posttest. So, the pre-test given in order to know how is students' speaking ability before giving the treatment. After giving treatment, the students were given post-test with the same task. So, it would be known whether the students' speaking ability increase or not. If students' speaking ability is increased, it can be said that the technique used was effective.

\section{Technique of Data Presentation and Analysis}

Observation aimed to know whether the technique procedures were implemented or not; that is impromptu speech technique, while speaking test for knowing students' speaking test result.

In analyzing the data, the researcher used checklist on observation list and scores of pre-test and post-test of experimental as well as and control group. These scores were analyzed statistically by using independent sample T-Test from SPSS 20 version:

identic

$$
\mathrm{Ho}=\text { Variance population }
$$

$\mathrm{Ha}=$ Variance population not identic If probabilities $>0.05$, Ho is accepted.

\section{FINDING AND DISCUSSION}

\section{The Students' Score of Pre-Test of Experimental Class}

Based on the score from the raters, students' average score in accent was 40, students' average score in grammar was 45, students' average score in vocabulary was 51 , students' average score in fluency was 45, students' average score in comprehension was 56, and students' average score of all was 47.4

\section{The Students' Score of Pre-Test of Control Class}

Based on the score from the raters, it can be concluded that students' average score in accent was 40 , students' average score in grammar was 43, students' average score in vocabulary was 43 , students' average score in fluency was 44, students' average score in comprehension was 51 , and students' average score of all was 45.4 .

\section{The Students' Score of Post-Test of Experimental Class}

Based on the score from the raters, it can be concluded that students' average score in accent was 
51 , students' average score in grammar was 55, students' average score in vocabulary was 59 , students' average score in fluency was 59, students' average score in comprehension was 69 , and students' average score of all was 61.6

\section{The Students' Score of Post-Test of Control Class}

Based on the score from the raters, it can be concluded that students' average score in accent was 43 , students' average score in grammar was 48, students' average score in vocabulary was 58 , students' average score in fluency was 51, students' average score in comprehension was 58 , and students' average score of all was 51.7

\section{Data analysis of Students' Post-Test Score of Experimental Class}

The data of students' post-test score of experimental class were obtained from the result of their speaking ability. Based on the description data in page 64 , the result can be classified the score as follows:

TABLE 8

The Classification of students' score of Experimental Class

\begin{tabular}{|c|c|c|c|c|}
\hline No & Categories & Score & Frequency & Percentage \\
\hline 1 & Very Good & $80-100$ & - & $0 \%$ \\
\hline 2 & Good & $66-79$ & 11 & $73.3 \%$ \\
\hline 3 & Enough & $56-65$ & 4 & $36.3 \%$ \\
\hline 4 & Less & $40-55$ & & $0 \%$ \\
\hline 5 & Fail & $30-39$ & - & $0 \%$ \\
\hline \multicolumn{4}{|c}{ Total } \\
\hline
\end{tabular}

Based on the table above, it can be seen that the classifications of the students' score: the category number 1 shows $0 \%$, the category number 2 shows 11 frequencies $(73.3 \%)$, the category number 3 shows 4 frequencies $(36.3 \%)$, the category number 4 shows no frequency $(0 \%)$, and the category number 5 shows no frequency. The table above also shows that the highest percentage of experimental class was $52.8 \%$. The mean score of experimental class was 70. Thus, the majority of the students in experimental class can be classified good category.

\section{Data analysis of Students' Post-Test Score of Control Class}

The data of students' post-test score of control class were obtained from the result of their speaking ability as follow: 
TABLE 9

\section{Classification of Students' Score in Control Class}

\begin{tabular}{|c|c|c|c|c|}
\hline No & Categories & Score & Frequency & Percentage \\
\hline 1 & Very Good & $80-100$ & - & $0 \%$ \\
\hline 2 & Good & $66-79$ & - & $0 \%$ \\
\hline 3 & Enough & $56-65$ & 10 & $66.6 \%$ \\
\hline 4 & Less & $40-55$ & 5 & $33.3 \%$ \\
\hline 5 & Fail & $30-39$ & - & $0 \%$ \\
\hline \multicolumn{4}{|l}{ Total } \\
\hline
\end{tabular}

Based on the table above, it can be seen that the classifications of the students' score: the category number 1 shows no frequency $(0 \%)$, the category number 2 also shows no frequencies $(0 \%)$, the category number 3 shows 10 frequencies $(66.6 \%)$, the category number 4 shows 5 frequencies $(33.3 \%)$, and the category number 5 shows no frequency. The table above also shows that the highest percentage of control class was $66.6 \%$. The mean score of control class was 54 . Thus, the majority of the students in control class can be classified enough category. The Data Analysis of the Improvement of Students' Speaking Ability by Using Independent Sample T-test

Table 10

\section{Group Statistics}

\begin{tabular}{|ll|c|c|c|c|}
\hline & $\mathrm{N}$ & Mean & Std. Deviation & Std. Error Mean \\
\hline Experiment & Class & 15 & 12.67 & 7.87038 & 1.31173 \\
Control Class & 15 & 3.31 & 5.90001 & .99728 \\
\hline
\end{tabular}

Based on the table above, it can be seen that the total students' from each class, the experimental class consisted of 15 students; while for the control class consisted of 15 students. The mean of Experimental class improvement was 12.67 , and mean of control class improvement was 3.31. Standard deviation from experimental class was 7.87038, while standard deviation from control class was 5.90. Standard error mean from experimental class was 1.31, and control class was .99728 . 
Table 11

Independent Sample Test

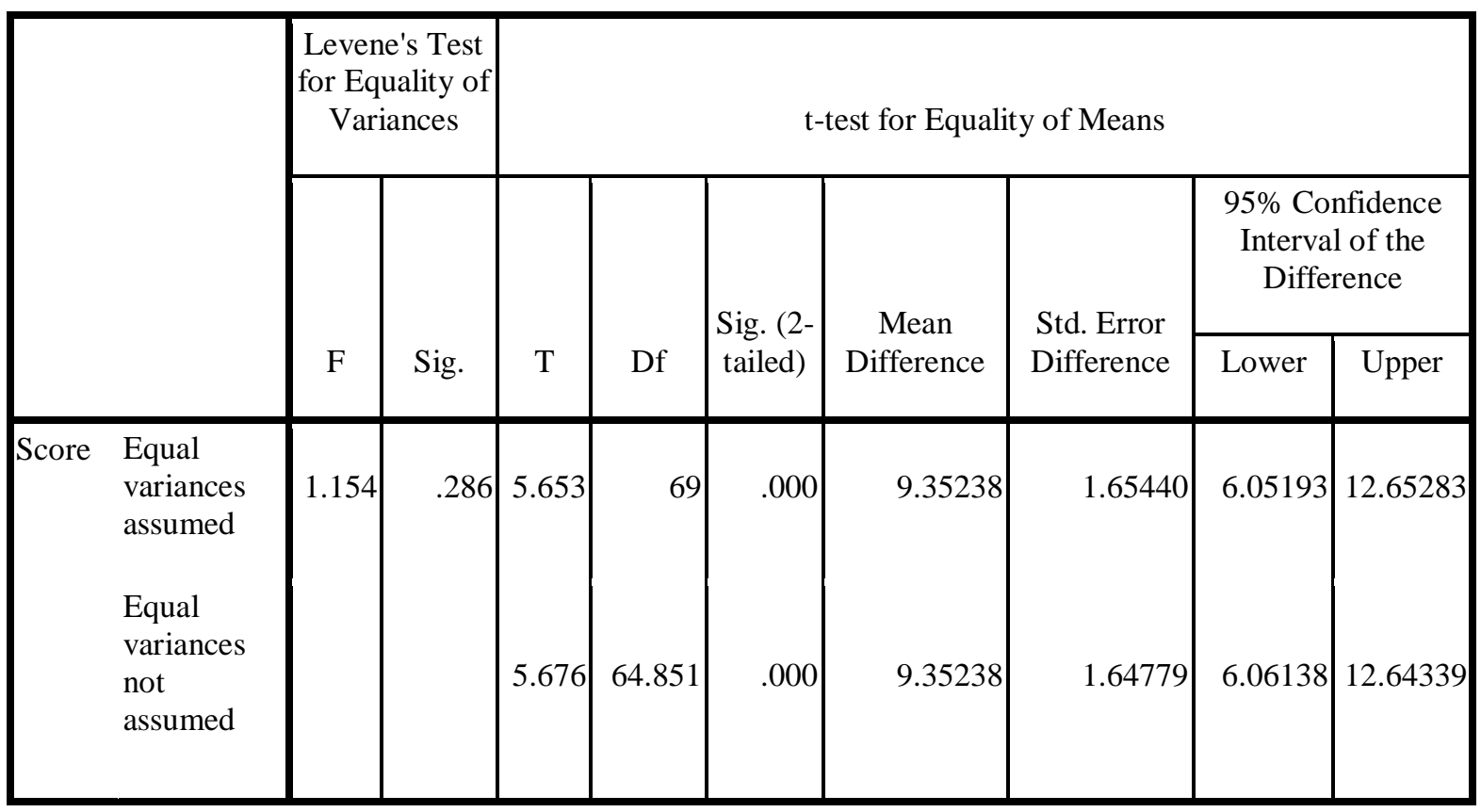

Based on the output SPSS

above, we could see that $t_{\text {scorein }} 2 \operatorname{sig} 2$ tailed was 0.000 and it was lower than

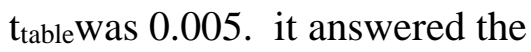
hypothesis of the research that $\mathrm{Ha}$ is accepted because $0.000<0.05$. It means that Ho is rejected.

\section{CONCLUSION}

From analysis of Independent Sample T-Test formula, there is a significant difference of improvement of students' speaking ability who were taught by using impromptu speech technique at the fourth semester students STIBA PersadaBundaPekanbaru. The $\mathrm{Ho}$ is rejected and $\mathrm{Ha}$ is accepted because $0.000<0.05$. Besides, Mean students' score in pre-test at experimental class is 47.4. Mean students' score in post- test at experimental class is 61,6. From the calculation above, clear that students' speaking ability in experimental class increases. While, Mean students' score in pre-test at control class is 45.7. Mean students' score in post-test at control class is 51.7., It means that the effect of impromptu speech technique is better than natural approach as the conventional way. The writer suggests to readers to apply Impromptu speech technique to improve students' speaking ability that had been proven in this research.

\section{REFERENCES}

Alderson, J. carles. 2004. Assessing Speaking. New York: Cambridge University press 
Betty Schrampfer. 1989. Understanding and Using English Grammar. New Jersey: Prentice Hall Regents, 1989.

Ag. Bambang Setiyadi. 2006. MetodePenelitianPengajaran Bahasa Asing; PendekatanKuantitatif dan Kualitatif. Yogyakarta: Grahallmu.

Brown, H. Douglas. 2004. Language Assessment: principle and Classroom Practices. New York: San Francisco State University

Brown, James Dean. 1995. The Elements of Language Curriculum. Boston: Heinle and Heinle Publisher

B-Ikeguchi,Cecilia. 2010. Training for Impromptu Speaking and Testing Active Listening. http://iteslj.org/Techniques/lke guchi-Speaking.html.

Bratt Paulston, Christina. 1976. Teaching English as a Second Language: Techniques and Procedures. Cambridge: Winthrop Publisher.

Carstairs, Andrew. 2002.An Introduction to English Morphology: Words and their structures. $\quad$ Edinburgh: Edinburgh University Press

Croswell, John M. 2008. Educational Research: Planning, Conducting, and Evaluating, Quantitative and Qualitative Research. New Jersey: Merrill Prentice Hall
Cyril, J. Weir. 1990. Communicative Language Testing. New York: Prentical Hall,

C. Richard, Jack and S. Rodgers, Theodore. 1979. Approach and methods in language teaching: a Description and Analysis. New York: Cambridge University Press Cambridge

E. Williams, David at all. Is It Time for a Change in Impromptu Speaking. 1992. Retrieved on December 3rd 2011 cas.bethel.edu/dept/comm/nfa/ journal/vol11no1-3.pdf.

Fillmer, H.Thompson. 1977. Patterns of Language. New York: Litton Educational publishing, Inc..

Flanders, Cathrine. 1979. The Challenge of Effective Speaking. United States America: Wadsworth Publishing Company,Inc

Gay, L.R and Peter Airasian. 2000.Educational Research Competencies for Analysis and Application. New Jersey: Prentice-Hall, Inc.,

Hughes, Arthur. 2003.Testing for Language Lecture. United Kingdom: Cambridge University.

Harmer, Jeremy. 1998.How to Teach English: An Introduction to the Practice Language Teaching. England: LongmanHou,

Minghua. 2011. A New Approach to Public Speaking Course in ESL classroom. China. 2008. Retrieved on January 5th 2011 
www.Ccsenet.org/journal.html http://en.wikipedia.org/wiki/I mpromptu_speaking

KalayoHasibuan and Muhammad Fauzan A. 2007. Teaching English as Foreign Language (TEFL). Pekanbaru: Alaf Riau Graha UNRI Press.

Mcdonough, Jo. 2003. Materials and Methods in ELT: A Lecture's guide. Australia: Blackwell Publishing

Menguin, Jef. Speaking off the cuff. Retrieved on December 18th 2010.

www.shtm.org.au/pdfs/Impro mtuSpeakingHints.PDF/http:// www.scribd.com/mobile/docu ments/search?query=Speaking + Off + the + Cuff \& commit=Sear ch, 2010.

M. Syafi'i S. Et al. 2007. The Effective Paragraph Developments: The Process of Writing for Classroom Setting. Pekanbaru: LBSI

Nunan, David. 2003.Practical English Languge Teaching. Sydney: Mc Graw Hill, Inc

Newton, S. P. 2009.Teaching ESL/ EFL Listening and Speaking. New York: Routledge

SuharsimiArikunto. 2010.DasardasarEvaluasi Pendidikan. Jakarta. BumiAksara. 2006. ProsedurPenelitian; SuatuPendekatanPraktik. Jakarta: PT. AsdiMahasatya.

Thornbury, Scott. 2006. An A-Z of ELT: A Dictionary of Terms and Concepts used in English Language Teaching.

Malaysia: Macmillan
Ur, Penny. 1991. A Course in Language Teaching: Practice and Theory. New York: Cambridge University Press

Williamson, Lynette. 2008. On Demand Writing: Applying the Strategies of Impromptu Speaking to Impromptu Writing. USA: debate Press. 